\title{
An Examination of The Threats of Climate Change, Herdsmen Migration and the Proliferation of Arms: Issues, Challenges and the Way Forward in Southeast Nigeria
}

\author{
Obuzor Mezewo Emerinwe ${ }^{1}$ Grace A.T Scent, Ph.D ${ }^{2}$ \& CHUKWU, Christian Chima, $\mathrm{PhD}^{3 *}$ \\ 1. Department of Sociology, Faculty of Social Sciences, Rivers State University, Nkpolu, \\ Oronworukwo, Port Harcourt. ORCID: 0000-0001-7836-3977 \\ 2. Department of Sociology and Anthropology, Niger Delta University, Wilberforce Island, Nigeria. \\ ORCID: 0000-0001-8846-6881. \\ 3. Department of Sociology, Novena University, Ogume, Delta State, Nigeria. \\ E-Mail: chukwuchidr@gmail.com; ORCID: 0000-0002-4290-234X;
}

\begin{abstract}
The central discourse of this study is on climate change and its implications on herdsmen migration, and proliferation of arms: issues, challenges and the way forward in southeast Nigeria. The hazards of climate change conditions which necessitated herdsmen migrations down southeast in search of pastures for their cattle, have turned caustic by the invasion of farmlands owned by host communities with impunity thereby causing bloodbaths. To this effect, the study focuses primarily on the need to create a human environment where the quality of life of Nigerians in the southeast will be greatly enhanced through mitigating all processes that promote climate change. To achieve the objectives of the study, two research questions were formulated to guide the study. Literatures related to the variables were reviewed including the adoption of a purposive sampling technique to select 300 respondents who constituted the data for the research. Theory of Eco-Violence was used as theoretical framework to guide the study. In-depth Interview (IDI) and Focus Group Discussion (FGD) were used to elicit data from the respondents. Qualitative analysis was employed to assess the two research questions. Among the findings, the study revealed that climate change processes have affected the biophysical life support system including vegetation, water resources, soil and atmosphere which constitute the elements that support the long term sustainability of life on earth. In addition, the study also showed that climate change has precipitated resource conflicts between herdsmen and host communities leading to loss of lives and destruction of properties running into billions of naira. Again, that government inability to make any arrest seem to suggest covertly that the herdsmen are being protected and this has over time impacted negatively on the various segments of society. Furthermore, the dismissal of the detestable killings of farmers by herdsmen as being the handiwork of foreigners, while doing nothing to halt the incessant atrocities against the root and tuber farmers in the south remains worrisome for a government that claims to respect human lives. The study concludes that southeast Nigeria has had unfair share of climate change hazards such as herdsmen migration, proliferation of arms, bloodbath visited upon host communities for resisting the destruction of crops. Finally, study recommends that government should start being proactive in curtailing the menace of herdsmen, and putting down all time tested policies to checkmate the hazards of climate change. In addition, all anthropogenic factors should give way for sustainable development to take precedence.
\end{abstract}

Keywords: Climate change; Herdsmen, Proliferation of arms, Resource scarcity

DOI: $10.7176 /$ RHSS/10-4-16

Publication date: February $29^{\text {th }} 2020$

\section{Introduction}

One of the most serious challenges that have become factual in contemporary Nigerian society and the entire human race is the effect of climate change on the achievement of Sustainable Development Goals (SDGs), the centerpiece of the 2030 Agenda for Sustainable Development, adopted during the 70th session of the United Nations General Assembly. It is therefore in attempting to avoid the environmental crisis looming on man, the pride and joy of Sustainable Development Goals (SDGs) that an extraordinary summit was convened by United Nations member states. The assembly concluded with the adoption of the declaration "Transforming Our World - the 2030 Agenda for Sustainable Development”, a universal call to action for the betterment of people, planet, 
prosperity, peace, and partnership which is unprecedented in both scope and ambition. But since its adoption, the effects of climate change, unrelenting like a whirlwind, on man's survival on planet earth, predominantly his biophysical life support system including vegetation; water resources, soil and atmosphere are worrisome.

While man continues to suffer from these environmental hazards, it is important to recall that when nothing was said or known about climate change, John Kennedy, the $35^{\text {th }}$ President of United States drew the world's attention to the fact that the entire society rest upon and is dependent upon our water, our land, our forest and our minerals, for the way and manner we use these resources influences our health, security, economy and wellbeing. Perhaps, as an environmental prophet, he called for serious commitment, particularly proactive actions to safeguard the environment so that man's survival on earth planet would not be threatened by climatic changes in the near future. Unfortunately, his thoughts were seemingly insignificant and thus taken for granted for the reason that there was little reflection that climate change could ever be a problem. Consequent upon this negligence, climate change, whether at the global, national or state or even local scale, has affected perilously, the productive sectors such as agriculture and then the economy of vulnerable areas (Karmaoui, 2019). It has increased drought events (Anderegg et al. 2013), which lead to increases in desertification (Wonkka et al. 2016). Generally speaking, the inordinate activities of man, called anthropogenic, and other natural occurrences are having adverse consequences on the environment due to the rises in gases called greenhouse gases.

Evidently, one of the grimmest costs of climate change is not necessarily the heavy droughts and famine, erratic weather seasons, prolonged dry spells, scarcity of natural resources, degradation of the environment, deprivation and uneven allocation of natural resources, and food shortage, but the absolute change in our pattern of living. Importantly, the hazards from these anthropogenic factors, have taken their toll on the socioeconomic wellbeing of the people living in southeast Nigeria. Overall, the effects of climate change are, aside from being critical, have been one of the challenges affecting the overall productivity of man in southeast Nigeria. Undoubtedly, the increasing concentration of Green House Gases (GHGs), namely, Carbon dioxide $\left(\mathrm{CO}_{2}\right)$, Methane $\left(\mathrm{CH}_{4}\right)$ and Nitrogen dioxide $\left(\mathrm{N}_{2} \mathrm{O}\right)$ has raised and withheld the amount of heat that was supposed to be radiated back into space from the sun to be suspended in the atmosphere. The resultant effects have been a sharp rise in droughts, desertification and famine, erratic weather seasons, degradation, and, in some areas like in the northern Nigeria, prolonged dry spells, natural resource scarcity and depletion of natural resources including water. Moreover, the shrinking of the glacier volume of the warming temperature on the earth's surface shows the farreaching effect of climate variability. Concurring, Harriet \& Peter(2010) rightly observe that the most vulnerable are the most exposed, having the least means to adapt to these emissions as they know no boundaries; emissions in one place and time contribute to increasing atmospheric concentrations of these gases which in turn have negative impacts across the globe. Following this, the United Nations system has had a long history of involvement in addressing the consequences of human activity on the global environment. Contributing to the discourse, Geoffrey Heal (1999) states that since the first UN Conference on the Human Environment in Stockholm in June 1972, the number of UN and related institutions and mechanisms dealing with the global environment generally, and climate change more specifically, has increased markedly. This proliferation has not, Adrian Smith (2009) argues, been a comfortable one because different ideas about how to deal with global environmental degradation have combined with diametrically opposed driving ideologies and different organizational remits to generate a constellation of institutions with little coherence and, as a result, limited capacity. In spite of this, one positive outcome has been that the environment has come to be a major concern for even the most reluctant of global institutions, even if navigating the various roles of myriad bodies in this area has become more problematic (Adrian Smith, 2009).

Over the last century, atmospheric concentrations of carbon dioxide increased from a pre-industrial value of 278 parts per million to 379 parts per million in 2005, and the average global temperature rose by $0.74^{\circ} \mathrm{C}$ making it the largest and fastest warming trend that the body has been able to discern in the history of the Earth (IPCC, 2007). Buttressing the fact further, the IPCC maintains that there has been an increasing rate of warming, particularly over the last 25 years, and 11 of the 12 warmest years on record have occurred in the past 12 years. Sustaining her position, the IPCC Report (2007) shows that global warming will continue to rise, particularly going by the projections for the $21 \mathrm{st}$ century. According to the best estimates, the earth could be warmed by $3^{\circ} \mathrm{C}$ by 2100 range from a minimum of $1.8^{\circ} \mathrm{C}$ to as much as $4^{\circ} \mathrm{C}$ rise in global average temperatures. Based on this, climate change has acquired global currency as never before. Corroborating the aforesaid, climatologists have 
shown that there are strong causal relationships between global climate change and human conflicts across various geographical spaces in the past. According to a study by Solomon Hsiang (2013), the magnitude of climate's causal influence on conflict incitement is substantial: the warmer climates got in the past, the higher the frequency of interpersonal violence and intergroup conflicts rose. Hsiang predicts that, amplified rates of human conflict could be a critical impact of anthropogenic climate changes as global temperatures are expected to rise by 2 degrees Celsius to 4 degrees Celsius by 2050. These predictions are already manifesting in different parts of the world. For example, the world's freshwater reserves are quickly depleting; Organization for Economic Co-operation and Development's Environmental Outlook predicts that by 2030, 47\% of the world's population will be living in areas of high water stress. Contributing earlier, Valerie (2010) noted that: Water is a key resource for sustaining life and society through agricultural production, industry, and hydropower, as well as health and human development at large. According to him, no community and economy will prevail without water of sufficient quality and quantity. In other words, water and security are basically interconnected in two ways: Resource crisis occurs over water if the amount available is grossly inadequate and as a result, competition increases. Extending the submission, Houdret \& Carius (2010) contend that water insufficiency could influence human security and possibly leading to instability, migration, and amplified resource competition.

The adverse climatic and environmental impacts that occur today are manifestations of man's inadvertent modifications to climate in some activities of the distant past. Consequent upon the insensitivity of man on activities leading to climate change, the African Union, AU, and the Security Council of the United Nations(2007), held their first ever debate on the security implications of climate change. Furthermore, at Durban, South Africa, the issue occupied the front burner during the 17th meeting of the Conference of the parties to the Kyoto Protocol in November, 2011.

In addition, the conference incorporated the twenty-second Conference of the Parties (COP22), the twelfth meeting of the parties for the Kyoto Protocol (CMP12), and the first meeting of the parties for the Paris Agreement (CMA 1). The purpose of the conference was to prevent "dangerous human interference with the climate system", and go ahead to implement plans about combating climate change and to demonstrate to the world of the implementation of the Paris Agreement. The members of the United Nations Framework Convention on Climate Change (UNFCCC) constituted the participants. All the three gatherings, including the UN Convention on Biological Diversity, and the Convention to combat Desertification, and considered and adopted the' Rio Convention' agreed upon at the Rio Earth Summit in 1992.

Fundamentally, climate change has become global problem that can no longer be ignored as in the past as it is now proven that the emissions of Carbon dioxide, Methane, Nitrogen (IV) oxide, the Hydro fluorocarbons, Sulphur hexafluoride and Perl fluorocarbons are hazardous to man despite the denials an counter denials by the world's super powers that emit most of these gases at higher proportions than any other. Whether admitted or not, the fact remains that as the emission of these gases increases, the earth's temperature also rises leading to global warming with its attendant consequences on man's sustainability. Writing further, Williams (2013) states that with this rise in temperature, there has been a continued increase in the sea-level at a proportion of about $1.7 \mathrm{bmm} /$ year over the past one hundred years, which is evidence for global climate change.

While opposing these environmental hazards, it is saddening to observe that multi-national corporations that have over the years been making billions of dollars in the production of goods and services that accelerate climate change see the idea of climate change as dirty. Even though their excessive activities contribute to climate change, and would require costly regulations and expensive (Sharma, 2007) operational upgrades to stop it, the decision to discredit the concept of climate change as dirty is understandable. What is more, the rebuttal, despite the negative consequences, if not done, would be disastrous because their exploitative business activities would be run down. In other words, they prefer making huge economic profits at the detriment of protecting and safe guiding the environment. All the same, the denial has become like the case of an ostrich that runs very fast to hide itself in the sand unknown to it that the whole body is still visible to every passerby. However, as they continue to justify their position, there have arguments and counterarguments. Thus, it is imperative to state that whichever side the argument goes, scholars of environmental management, sustainable development and human health, have averred that global warming, environment degradation, ozone depletion and deforestation are caused primarily by human influences called anthropogenic factor including the market mode of production (Sharma, 2007). Eddie N. LaboyNieves, et al., (2009) make better the submission of Sharma's position by holding that the expansion of industries 
and domestic markets has drastically altered the atmospheric concentrations of numerous trace gases. By implication, this has resulted in rapid increases in the consumption of hydrocarbons. As a result, the world is currently faced with several environmental troubles and these myriad of challenges have distorted nature's autobalancing mechanism with negative impacts on the welfare of millions of people.

Migration is a rational drive undertaken by herdsmen to save and protect their cattle from adverse climatic conditions. However, Flavell (2010) affirms that in the initial stages of environmental degradation, migration represents a logical and lawful livelihood diversification alternative. He further argues that migration is an adaptation approach that people affected by hostile climatic conditions employ to mitigate the effects of climate change. Substantiating, Flavell submits that when environmental degradation becomes severe, migration can become permanent and may require relocation of affected populations, either internally or externally. Therefore, there is nothing wrong in the migration of herdsmen downwards of the country in search for greener pastures for their cattle because climate change processes have affected the biophysical life support system in their abodes. In reality, the predicament of herdsmen demonstrates the reality of the climate change and resource control interface, and its embedded security challenges. With the scarcity of water and shrinking of grazing fields, the subsequent migration of herdsmen is a welcome development. But the migrations have been with disregard and contempt for host communities leading to skirmishes as a result of the forceful bid to seize and graze their cattle on farmers' crops. This singular act has led to the wanton loss of lives and properties running into billions of dollars on both sides. However, it is evident that the threat posed by Fulani herdsmen in the different communities they migrated to for purposes of grazing their cattle is disturbing.

The escalations of reported attacks by Fulani herdsmen who brutally kill natives of the invaded farming communities including women and children in various states across the country is shocking.. Substantiating, Ekemenah(2017) avers that prior and after the return to civil democratic rule in 1999, it has been a recurrent decimal on the security plane to hear regular reports about wanton killing of people and destruction of farmlands and other properties by Fulani herdsmen. In order to avoid ruffling political feathers, the reportages are often laced with evasive words such as "suspected" Fulani herdsmen. Obviously, these murderers and killers, according to are not aliens (Alex Ekemenah, 2017). According to Ekemenah, they are also not foreigners. There are no more doubts that they are Fulani herdsmen (fellow Nigerian citizens) whether we like to be specious or economical with the facts of each case. He concludes that it has also become loud and clear that rarely do other class or category of people embark on such murderous trail for the fun of it. Apparently, Ubelejit (2016) asserts that the threat posed by the migration of herdsmen to different communities for purposes of grazing their cattle are very painful. For example, the unlawful invasion and devastation of farmlands by herdsmen which in 2004 was named the fourth deadliest terrorist group in the world by the Global Terrorism Index have culminated in the worsening and unending incidence of conflict between herdsmen and farmers in the southeastern part of Nigeria to the extent that Nigerians and International Observers including the United States have considered Fulani herdsmen as the second most dangerous group in Nigeria after Boko-Haram group (GTI, 2015). Clearly, contemporary scholars of climate change have opined that by this callous act, the activities of herdsmen have impacted negatively on all segments of the Nigerian society they have migrated to, especially the southeastern part of country. With no remorse for destroying farmers' crops, and the arrogant claim that they have equal access to land in their host communities gives one much food for thought but hardly any for the stomach. Based on this, it is upheld by most researchers that they are clandestinely been supported by State authority, while nothing is done to halt the incessant atrocities against root crops farmers in the open as if they are responsible for the adverse effects of climate change on their abodes.

Perhaps, it is in realization of this aberration that the Intergovernmental Panel on Climate Change, IPCC (2007), in its Fourth Assessment Report, AR4, dispelled many uncertainties about climate change and states that warming of the climate system is now unequivocal. Following this, the panel declares that global warming is mostly due to man-made emissions of greenhouse gases (mostly $\left.\mathrm{CO}_{2}\right)$ and unless something serious is done, climate change will envelope all and sundry with disastrous consequences. Based on this, Bulkeley and Newell (2010) stress that climate change and other news reports of climate-related disasters are both at the pinnacle of the international political agenda and also one of significant public interest. What is more, it has been suggested that if the current trends of anthropogenic GHG emissions continue through 2030, the earth is likely to experience an average rise in temperature ranging from $1.5^{\circ} \mathrm{C}$ to $4.5^{\circ} \mathrm{C}$. In addition, it is also agreed that the activities of 
developed nations are mostly accountable for climate change, but that developing nations such as Nigeria, are those suffering from the consequences more due to inability to cope as a result of poverty and low technological development. Based on this, it is estimated that between 75 million and 250 million people in Africa may be exposed to increased stress like scarcity of water, environmental stress and food security stress, due to climate change by 2022

Agreeing with this assertion, scientific studies have shown that snows are disappearing rapidly and secondly, there has been the growing absorption of greenhouse gases (GHGs) in the atmosphere which attracts and discharges infrared radiation that is gradually upsetting Nigeria's ecosystem. In all directions, it is pertinent to acknowledge the fact that climate change impedes development and intensifies income disparities between rich and poor and ultimately degenerates into conflicts between landowners and herdsmen (Ubelejit, 2016). Earlier, Sawin (2013) had submitted that "climate change could undermine efforts to mitigate world poverty, and directly threatening people's homes and livelihoods. Not only could this impede development, it might also increase national and regional instability and intensify income disparities between rich and poor."

Admittedly, climate change has over the years disrupted the normal functioning of the ecosystem that interacts with humans, and this has affected how man accesses certain ecological resources for his survival. Therefore, the major alternative is to migrate to other environments and confronts less of the climate hazards. The case of herdsmen is a perfect illustration of such migrations because of persistent droughts and desertification in the Northern part of Nigeria.

\subsection{Statement of the problem}

Climate change processes have affected the biophysical life support system including land surface (vegetation), water resources, soil and atmosphere which constitute the elements that support the long term sustainability of life on earth. Climatic challenges have stressed, destroyed and depleted natural resources to the extent that land and water are in shorter supply. A lot of communities that are heavily dependent on natural resources seem to find no solutions to climate change as it has continued to significantly undermine their livelihoods and growth. There has also been increasing concentration of greenhouse gases (GHGs) into the earth's atmosphere that absorbs and emits infrared radiation or heat through the use of fossil fuels. These greenhouse gases include carbon dioxide $\left(\mathrm{CO}_{2}\right)$, methane $\left(\mathrm{CH}_{4}\right)$ and nitrogen dioxide $\left(\mathrm{N}_{2} \mathrm{O}\right)$, and a rise in these gases has caused a rise in the amount of heat from the sun withheld in the earth's atmosphere, heat that would normally be radiated back into space. This increase in heat has led to the greenhouse effect, resulting in climate change. There have been increases in average global temperature (global warming); changes in cloud cover and precipitation particularly over land; melting of ice caps and glaciers and reduced snow cover; and increases in ocean temperatures and ocean acidity - due to seawater absorbing heat and carbon dioxide from the atmosphere. Nigeria as a part and parcel of the world is not immune to climate change hazards. Essentially, climate change in Nigeria has over time disrupted the normal functioning of the ecosystem that interacts with humans, and affects how they access certain vital resources for their survival. When climate change hazards such as heavy droughts and famine, erratic weather seasons and, in some areas like in the north, prolonged dry spells occur in Nigeria, it is normally viewed in relation to environmental degradation, natural resource scarcity, migration and food shortage. In this vein, conflicts between cattle herders and farmers over these scarce resources have led to incessant and escalating bloody clashes culminating in the loss of life and wanton destruction of properties. Basically, the frequency and scale of these conflicts have become alarming. Conflicts between farmers and cattle herders have constituted serious threats to the means of survival and livelihoods of both the farmers and cattle herders and what both groups are tenaciously protecting and projecting. This movement downward to the southeast coast due to climate change has generated serious disturbance for the host communities.

It is therefore the objective of this paper to provide an understanding of climate change and its implications on herdsmen migration, and proliferation of arms: issues, challenges and the way forward in Nigeria, particularly in the southeast where abundant farmlands have been destroyed and owners either killed or maimed by herdsmen. The specific objectives this study is two- pronged, and are outlined hereunder:

(a) To examine the impact of climate change on herdsmen migration

(b) To assess the security implications of climate change on the of the proliferation of small arms and light weapons amongst herdsmen 
In the attempt to achieving these objectives, two research questions were also formulated to guide the study. These are:

(a) What is the impact of climate change on herdsmen migration?

(b) What is the security implication of climate change on the proliferation of small arms and light weapons in the hands of herdsmen?

In view of these questions, Durojaiye (2014) avers that there have been escalations of reported attacks by herdsmen who brutally kill natives of the invaded farming communities including women and children in various states across the country in order to take possession of their land. The total disregard and contempt herdsmen exhibit in grazing their cattle on farm lands not owned by them constitutes serious threat to host communities, particularly with streams being regularly been polluted and contaminated by the droppings of cattle. The costs in lives, property, political and economic stability are always devastating whenever these violence surface, and whether admitted or not, the skirmishes over natural resources have significant security implications for Nigeria's corporate existence. But today, every other Nigerian is afraid either of the Boko Haram or the nomadic pastoralist (Abati, 2016). It is not likely that the populations southeast Nigeria will continue to stand idly by and allow herdsmen to trample upon their lands, destroy their crops, kill, maim and rape and then get away with it. A resort to self-help such as occurred in 1966 could have serious national security implications. With the economy in crisis, with anger in the land, and the people feeling disappointed, they cannot afford any evil trigger to deepen their woes. In view of all this, one is tempted to ask: Does the destruction of the livelihood of others, while securing one's own with sophisticated weapons that make this evil possible acceptable? The evidence from this senseless destruction would, certainly, suggest that herdsmen are not only looking for pastures for their cattle, but for something that most southern Nigerians have on the tips of their lips but cannot categorically state how possible it will be in this modern age. According to Ovuakporie and Agbakwuru(2016), the persistent attack by the herdsmen has prompted many Nigerians to regard herdsmen as being more dangerous than Boko-Haram since the latter activities are limited to North-Eastern part of the country whereas herdsmen are everywhere. For a long period now, the country's media has been dominated by reports of maiming, killings, rape and other forms of banditry associated with highly armed herdsmen, but nothing concrete has been done by the security architecture headed by a section of the country that is in power. This constant rising crescendo of the uninterrupted herdsmen crises that occur at the least provocation has given many armed groups the freedom to operate according to their own rules, and to carry out serious human rights abuses with impunity. As would expect, these incessant killings have continued to breed inexplicable fear into the psyche of southeastern Nigerians on whose lands these atrocities are constantly been committed despite the country's fifth attempt at democratization.

\section{Material and methods}

\subsection{Study area}

The study was carried out in south east region of the country, otherwise known as Igbo land. The Igbo constitutes one of the three major ethno-cultural and linguistic groups in Nigeria. The Igbos cover an area of about 15,800 square miles, and stretches across the River Niger from the West of Agbor to the fringes of the Cross River and running roughly from North of Nsukka highlands to some parts of the Atlantic coast. They are bounded on the East by the Ibibio and Efik nations, on the Southeast by the Cross River, on the Southwest by the Ijaw and Igado ethnic groups, and on the Northern parts by the Idoma, Akpoto and Mushin ethnic nationalities. The said geopolitical zone covers five states of the federation, namely, Abia, Anambra, Ebonyi, Enugu and Imo States. Purposively, the area was narrowed down to three states, namely, Abia, Ebonyi and Enugu states where hostilities between farmers and herdsmen seem to be on an increase.

\subsection{Descriptive survey design}

The study adopted the descriptive survey design, defined by Orodho (2009) as a systematic empirical method of collecting information by interviewing a sample of respondents and it is the most frequently used method for collecting information about people's habits in a variety of social issues. According to Mugenda and Mugenda (1999), it is the best method available to social scientists who are interested in collecting original data for the purposes of describing a population which is too large to observe directly. Based on this, the target population in this study consists of a purposively selected 300 respondents drawn from the selected three states earmarked for 
the study. By implication, one hundred respondents are drawn from each of the three states, and this accessible population is seen as typified, reasonable and represent the target population.

In-depth-Interview (IDI) is a type of data collection technique that involves oral questioning of respondents individually to obtain in-depth information on the threats of climate change, herdsmen migration and the proliferation of arms: issues, challenges and the way forward in southeast Nigeria which was of utmost importance to the researchers. This method was employed to gather data from herdsmen who were convinced to be part of the study through the assistance of three research assistants who conducted the face-to-face interviews in Hausa language. It was characterized by extensive probing and open-ended questions. There was an interview guide that included a list of questions meant to be explored and suggested probes for follow ups, using cues from study objectives. The interview was usually unstructured as it encouraged capturing of respondents' perceptions in their own words; a very desirable strategy in qualitative data collection.

Also the Focus Group Discussion (FGD) was employed to compliment the In-depth-Interview (IDI). Focus group discussion is primarily a qualitative method of administering open-ended questions in non-directive interviewing manner which is increasingly popular in the evaluation in human service programmes and researches in social sciences. The purpose of FGD in this study was to obtain in-depth information on beliefs, opinions, attitudes, concepts, perceptions and ideas of a group of participants on the subject matter. Participants are recruited purposively before the discussion began. In conducting the five different sessions, the researchers in collaboration with the three research assistants who also served as interpreters, the discussion did not exceed forty to sixty minutes. This was done to ensure that the discussions did not become boring and leading to disinterest. A guide was developed from the study objectives to moderate the discussion mainly on the subject of interest. The use of open-ended questioning format was preferred as it did not inhibit full discussion. A tape recorder was used by one of the research assistants to record discussions, and another served as an observer noting the non-verbal cues and group dynamics. The venue was conducive with no disturbances, sufficient quietness, and above all, the FGD was conducted in a neutral setting which encouraged discussants to freely express their views.

\section{Theoretical Framework}

\subsection{The Theory of Eco-Violence}

In order to assess the interactions and impacts of drought and desertification on the socio-economic, and biological resources of the region that necessitate herdsmen migration down southeast Nigeria, Thomas Homer Dixon theory of eco-violence (1998) fits into the analysis, particularly the proliferation of arms in the resource conflicts. According to Thomas Homer Dixon, we are on a "threshold" of an era in which armed conflict will rise with increasing frequency as a result of environmental changes. In this instance, since the continued existence of herdsmen in their cattle rearing occupation is highly dependent on two key environmental resources, namely, fresh water and lush grassland for their cattle, the scarcity or shrinking of these resources as a result of climate change has initiated for their migration to areas where these natural resources are abundant, and if found, no inquiry is made as to the right of ownership of these resources since the right of ownership of land, they assert, is foreign to them. This lack of respect for the right of ownership is the root of conflicts with herdsmen. Herdsmen violent conflicts in their quest to seize another pasture for their cattle with impunity, particularly with the mindset that landownership is strange to them have culminated to several deaths.

According to Homer-Dixon et al. (1998)

$$
\begin{aligned}
& \text {. . decreases in the quality and quantity of renewable resources, population } \\
& \text { growth, and unequal resource access act singly or in various combinations to } \\
& \text { increase the scarcity, for certain population groups, of cropland, water, forests, } \\
& \text { and fish. This can reduce economic productivity, both for the local groups } \\
& \text { experiencing the scarcity and for the larger regional and national economies. The } \\
& \text { affected people may migrate or be expelled to new lands. Migrating groups often } \\
& \text { trigger ethnic conflicts when they move to new areas, while decreases in wealth } \\
& \text { can cause deprivation conflicts (Homer-Dixon, \& Blitt, 1998) }
\end{aligned}
$$

The fundamental theoretical assumption of the theory, according to Odoh \& Chilaka (2012), is that resource scarcity is the product of an insufficient supply, too much demand or an unequal distribution of a resource as a 
result of environmental hazards that forces some sector of a society into a condition of deprivation and violence. According to Homer-Dixon, resource scarcity is a product of three different factors interacting: population growth, resource degradation and distribution of resources between individual groups (cited in Goldstone, 2005).Stressing further, he called it demand induced, supply induced and structural scarcity respectively. Of interest, supply induced scarcity is traceable to environmental degradation (Homer-Dixon et al., 1998) in which, the southeastern Nigeria provides a sorry example with the perennial conflict, attacks and counter-attacks between herdsmen and farmers in their region which has continually led to massive death toll of many innocent lives and actors involved in the conflict.

With drought and desertification ravaging the entire north of Nigeria, it is obvious that one basic reason for the migration of Fulani herdsmen is climate change. Within this context, the eco-violence theory systematically captures, and explicates the intricate linkages that develop between climate change and conflict between herdsmen and farmer in the southeast Nigeria. In analyzing the conflict, the attitude of the immigrants on the one hand and perception of host communities on the other hand is important. As accepted, resource conflicts between Fulani herdsmen and host communities usually arise when grazing cattle are not properly controlled and as a result, graze on cultivated plants like cassava, maize etc. in farms of host communities. Attempts by the owners of such farms to register their grievance at the wanton loss of their livelihood (food crops and cash crops) by herdsmen are stoutly resisted thereby degenerating into conflicts. In a nutshell, when communities attempt to moderate the inordinate activities of herdsmen or request their exit, they become aggressive and attack the host community sometimes with the assistance of hired mercenaries. Fulani herdsmen, according to Durojaiye(2014), normally attack host communities with sophisticated weapons, killing them, looting properties and burning houses at the time they are most susceptible such as mid-night or when they are in their churches.

Essentially, this theory helps to explain the link between climate change and conflict. That agriculture has almost been abandoned, particularly in the southeast due to herdsmen invasion into cultivated farmlands is no longer news. This situation has worsened considerably over the past couple of years as a result of government insensitivity to the plight of root crop farmers who suffer more as a result of climate change. From all this discourse, it is certain that with the scarcity of water and shrinking of grazing fields due to climate change, the subsequent migration of herdsmen is a welcome development. But their migrations have been with disregard and contempt for host communities leading to the wanton loss of lives and properties running into billions of dollars. Obviously, the herdsmen unwholesome activities have impacted negatively on all areas they have migrated to in the south east of Nigeria. In the several bids that have resulted in the confrontation with host communities with utter consternation, most researchers are of the view that the clandestine support of the federal authority is visible. It is in this vein that this study is embarked upon to understand climate change and herdsmen migration and the issues and challenges emanating there from and in the end proffer solutions to their nefarious activities in the southeastern part of Nigeria with a view of moving forward.

\section{Conceptual issues}

\subsection{Understanding climate and climate change}

Climate is the average weather-including temperature variances, precipitation and wind over a select period of time (Odoh, \& Chilaka, 2012). Succinctly, the term: climate, originates from the Ancient Greek word, Klima, meaning: inclination. It is commonly defined as the weather averaged over a long period. For Mayowa \& Omojola (2005), the standard averaging period is 30 years, but other periods may be used depending on the purpose. Climate also includes statistics other than the average, such as the magnitudes of day-to-day or year-to-year variations. What is more, the Intergovernmental Panel on Climate Change, IPCC, (2003), defines climate as: the average weather or more rigorously, over a period that ranges from months to thousands or millions of years. While this definition may appear narrow in scope, the Fourth Assessment Report, AR4, recognizes this lacuna, and observes in its new definition (IPCC, 2007) that: climate encompasses the statistics of temperature, humidity, atmospheric pressure, wind, rainfall, atmospheric particle count and other meteorological elemental measurements in a given region over long periods. It goes further to state that climate can be contrasted to weather, which is the present condition of these elements and their variations over shorter periods. However, the difference can further be viewed from the same old cliché: Climate is what you expect, weather is what you get. A region's climate is generated by the climate system, which has five components: Atmosphere, hydrosphere, cryosphere, land surface, and biosphere (Mayowa \& Omojola, 2005). An 
alteration in the quantity of atmospheric greenhouse gases determines the amount of solar energy retained by the planet, leading to global warming or global cooling (IPCC, 2003)

At this moment, perhaps, it is pertinent to ask the much awaited question: What is climate change? In response, the Intergovernmental Panel on Climate Change, IPCC, Third Assessment Report, AR3, (2003) classifies climate change as: a statistically significant variation in either the mean state of the climate or in its variability, persisting for an extended period (typically decades or longer). By extension, the increase in carbon dioxide is the major contributor to climate change. Carbon dioxide concentrations are increasing in the atmosphere primarily as the result of the burning of coal, oil, and natural gas for energy and transportation. Contributing, Mayowa and Omojola (2005) affirm that man's inadvertent modifications to climate in some activities of the distant past, and even present has raised the amount of heat that normally could have been radiated back into space from the sun to be suspended in the earth's atmosphere thereby leading to the increasing concentration of Green House Gases (GHGs), namely, Carbon dioxide $\left(\mathrm{CO}_{2}\right)$, Methane $\left(\mathrm{CH}_{4}\right)$ and Nitrogen dioxide $\left(\mathrm{N}_{2} \mathrm{O}\right)$ into the atmosphere. The resultant effects have been heavy droughts, desertification and famine, in some areas like in the north, prolonged dry spells, natural resource scarcity and depletion of natural resources including water. As a result, the atmospheric abundance of carbon dioxide is currently about $30 \%$ above what it was 150 years ago. The relative impacts on climate of various other "greenhouse" gases. In addition, there is an additional factor that indirectly links ozone depletion to climate change; namely, many of the same gases that are causing ozone depletion are also contributing to climate change. These gases, such as the chlorofluorocarbons (CFCs), are greenhouse gases, absorbing some of the infrared radiation emitted by the Earth's surface, thereby effectively heating the Earth's surface. Upholding this line of thought, climate change occurs as a result of any or all of these: natural internal processes or external forcing, or persistent anthropogenic changes in the composition of the atmosphere or in land use. Elucidating further, Ezirim and Onuoha assert that:

Climate change is caused by increasing concentration of greenhouse gases $(G H G)$ in the atmosphere. Greenhouse gases include any gas in the atmosphere that is capable, as a result of its particular molecular structure, of absorbing infrared radiation or heat. They a (sic) called greenhouse gases because they display effects similar to that in a "greenhouse". The glass in a "greenhouse" allows the sunlight to pass through but trapping the heat formed and preventing it from escaping, thereby causing a rise in temperature

(Ezirim, \& Onuoha, 2008)

Simplifying the description, Odoh \& Chilaka (2012) opine that climate change is:

a long-term shifts in temperatures due to human activity and, in particular, the release of greenhouse gases into the environment that leads to heavy droughts arising from prolonged dry spells, desertification, erratic weather seasons, scarcity of natural resources, degradation of the environment, deprivation of natural resources, erosion, food shortage, subsidence and other hazards by the actions of human influences called anthropogenic, and other natural occurrences (Odoh \& Chilaka, 2012).

The most fundamental reason for herdsmen migrate is desert encroachment (desertification) caused by climate change. Climate change destroys and depletes natural resources. As a result, climate change is making weather less predictable, especially in developing countries like Nigeria where facilities to predict and manage weather conditions are inadequate. The unpredictability of rainfall in recent times has continuously been causing untold hardship during the raining season. In this strand, Mayowa \& Omojola (2005) aver that "climate change is the variation in global or regional climates over time." It reflects changes in the variability or average state of the atmosphere over time scales ranging from decades to millions of years. Based on the foregoing, a lot of people in different communities heavily dependent on natural resources for their wellbeing are on the verge of collapse. This failure is as a result of climate change undermining the capacity of state to provide social services and economic opportunities requisite for state development and stability. Clearly, the lack of opportunities to sustain livelihood makes indigenes of such communities very susceptible to conflicts. Climate change not only triggers conflicts but can engender state failure. In an International Alert publication, Smith and Vivekananda (2007) observed that "threats to international stability associated with climate change, is placing some 40 states at risk of climate induced conflict." 
Consequent upon the insensitivity of man to climate change, the African Union, AU, and the Security Council of the United Nations(2007), held their first ever debate on the security implications of climate change. Further, at Durban, South Africa, the issue occupied the front burner during the 17th meeting of the Conference of the parties to the Kyoto Protocol in November, 2011. It would be recall that the National Oceanographic and Atmospheric Association (NOAA), and close to 200 countries signed the Kyoto Protocol, a document intended to engage countries in voluntary actions to limit the activity that leads to climate change. In addition, the conference incorporated the twenty-second Conference of the Parties (COP22), the twelfth meeting of the parties for the Kyoto Protocol (CMP12), and the first meeting of the parties for the Paris Agreement (CMA 1). The purpose of the conference was to discuss and implement plans about combating climate change and to demonstrate to the world that the implementation of the Paris Agreement is underway. In other words, the convention aimed to prevent "dangerous human interference with the climate system".

From the foregoing discourse, it is obvious that climate change is halting development, intensifying income disparities between richly endowed and poorly depleted communities and ultimately degenerating into conflicts for natural resources. Concurring, Sawin (2013) argues that "climate change undermines efforts to mitigate world poverty, and directly threatening people's homes and livelihoods.... Not only has this impedes development, there has been an increase in the national and regional instability that intensifies income disparities between rich and poor communities." In other words, climate change has the potentials of triggering severe disruptions with disastrous consequences for the people. Famines, droughts, and climate-change related disasters over years have claimed thousands or even millions of lives and aggravated existing strains within and among communities. Based on this, the subtle nature of climate change usually blurs its paroxysm to the extent that it is not usually seen as a major security threat. It is in this vein that Ezirim and Onuoha (2008) further observe that:

Climate change does not fit into the mode of traditional threats to national security such as war, terrorism, insurgency, espionage or sabotage. Yet its nonviolent and gradual dynamics of manifestation serve only to disguise its impact on livelihoods, social order, peace and stability (2008)

Agreeing with Ezirim and Onuoha, Odoh, \& Chilaka (2012) state that climate change is the increasing concentration of greenhouse gases, GHGs, in the atmosphere from the evolvement of the earth's climate system as a result of natural occurrences and human influences called anthropogenic. GHG is a gas in atmosphere that absorbs and emits infrared radiation or heat through the use of fossil fuels. As a result, the IPCC and other influential scientific assessments reflect important advances in the understanding of global warming and climate change. Based on this, they demonstrate most critically the historic magnitude of the pace and nature of these changes and underlines the urgency of efforts to reduce carbon emissions and to develop mechanisms to cope with climate impacts that cannot be avoided. It is in this vein that the Fourth Assessment Report, AR4, of the Intergovernmental Panel on Climate Change, IPCC (2007) observed that if greenhouse gases continue to be emitted unchecked, the climate system will change significantly in the 21 st century and that extreme climate phenomena and increasing sea levels will have adverse effects on natural and human systems.

\subsection{Climate Change and Herdsmen Migration}

The debate on climatic change and variability, according to Fasona and Omojola(2005), concentrate more on likely global and regional futuristic occurrences which may be triggered off by the climatic anomalies of the past and present. Based on this, climate change has acquired global currency as never before. Much as this is valid, Fasona, et al., (2005) further assert that the vulnerability and (likely) adjustments or coping mechanisms of people to the vagaries of climate is best understood at micro and meso levels. However, the predominant Fulani herdsmen of the lower Sahel and Sudan savannah ecologies have moved south - to the Guinea Savannah and Forest belt of the South - to find greener pasture for their herds. It is worthy to observe that their migration to the southeastern part of Nigeria is due to scarcity of water, and harsh weather in their previous abodes to where the ecology is more favourable to their herding business. In as much as Fulani herdsmen are completely dependent on resources of the natural environment, their movement was not acceptable to the root and tuber farmers who fear that Fulani herds would destroy their farmlands as they had done in other areas they had previously migrated. As expected, struggle for diminishing resources increased on arrival of the herdsmen due to climate variability. Consequently, conflicts over who owns the land and whose rights are to either cultivate or have access has continued without stop. 
Whatever direction the pendulum swings, it is an incontrovertible fact that climate change as a major contributor to resource conflict between farmers and herdsmen in the southeast.

Arguably, climate change has over the years disrupted the normal functioning of the ecosystem that interacts with humans, and this has affected how man accesses certain ecological resources for his survival. Therefore, the major alternative is to migrate to other environments and confronts less of the climate hazards. The case of population displacement viewed as the involuntary movement of people from one place to another as a result of natural or manmade disasters is a perfect illustration of such migrations because of persistent gully erosions. Based on the foregoing, the predicament of displaced persons demonstrates the reality of gully erosions resulting from climate change and its embedded security challenges.

In developed and developing countries, the concepts of migration and displaced populations have become issues of concern (IFRC, 2012). The United Nations Development Programme in 2009 gave a report of 214 million international and 740 million internal migrants that moved voluntarily for economic and other reasons. Those forced to leave their homes due to events beyond their control were more. Most of the displacements witnessed were in South and Eastern Asian Countries. According to United Nations High Commissioner for Refugees (UNHCR, 2011) avers that about 15 million people are refugees who have been forcefully displaced from their homes of origin. While in 2012, it was recorded that more than a million people are asylum seekers waiting status determination; whereby 15 million are displaced as a result of development projects; 26.4 million were internally displaced by conflict and 15 million displaced by natural disasters (IFRC, 2012). According to scholars of development of the nature of conflicts and disasters accompanied by its gargantum potential to uproot large numbers of people from one place to another have been witnessed within and across borders especially in countries like Haiti, Japan, Iraq, Pakistan, Mali, Syria and Nigeria. Nigeria's estimated figure of the displaced was about 3.3 Million. As at May 2014, 10\% of the displaced are traceable to communal clashes, natural disasters (IOM, 2016). The level of vulnerability heightened and involuntary migration seen in demographic factors such as population growth, rapid urbanization, increasing poverty and inequality, hazardous and environmentally contaminated sites, climate change, new technological hazards especially in Nigeria is pathetic (IFRC, 2012). Considering the number of recorded cases of human security challenge and its consequence on population displacement in Nigeria since 1999, recorded cases had been minimal.

It is generally agreed by scholars that the most fundamental reason why herdsmen migrate to other areas is because of desert encroachment (desertification) of the Sahel region caused by climate change. For Nte (2016), climate change has significantly undermined individual livelihoods and community growth thereby stalling the capacity of the state to provide social services and economic opportunities requisite for development and stability. Continuing, Nte (2016) further argued that communities exclusively dependent on natural resources are now on the verge of collapse as of climate change. Arguably, climate change accounts for the worsening incidence of conflict between Fulani herdsmen and farmers in southeast Nigeria.

Anchoring analysis on the eco-violence theory, the immediate reason for herdsmen and farmers' conflict is consequent upon natural resource scarcity that results to climate change. The drought and desertification visibly present clearly demonstrate man's unintentional modifications to climate. The drought and desertification visibly present clearly demonstrate man's unintentional modifications to climate. Thus, the Sahel zone, which is habitable by the Fulani communities, has been taken over by desertification thereby compelling the Fulani herdsmen to migrate towards coastal areas in search of pasture and water. Essentially, water, Valerie (2010) asserts, is a key resource for sustaining life and also for the development of society through agricultural production, industry, and hydropower, as well as health and human development at large. But the undesirable climatic and environmental impacts that occur today clearly demonstrate man's unintentional modifications to climate. Earlier, UNEP/GRIDArendal (2005) contended that most disasters (including flood, droughts, desertification, land degradation, subsidence, etc) are not random events without underlying causes. As earlier observed, they are sudden manifestations of slow but continuous degradation processes that lead to alterations in the biophysical life support system including land surface (vegetation), water resources, soil and atmosphere which constitute the elements that support the long term sustainability of life on earth. On the importance of water, no community can exist without water of sufficient quality and quantity. As a result, water insufficiency can influence human security and possibly lead to instability, migration, and amplified resource competition (Houdret and Carius 2010). This is supported by Gareth (1995) who observes that in developing countries, one of the greatest environmental threats 
is water, and acute water scarcity is distressing to an estimate of approximately 1.4 billion people are currently living in the Sahel zone. From this perspective, it is argued that the world's supply of water per capita is only onethird of what it was in 1970, and this scarcity is increasingly becoming a factor in ethnic strife and political tension. Elucidating further, the Intergovernmental Panel on Climate Change(IPCC,2016), more than 1.7 billion people currently live in African countries that are water stressed; meaning that they use more than (20\%) of renewable water supply.

From the foregoing, it is clear that the scarcity of land, water and foliage which stems from climate change have reduced the availability of nature-given resources thereby altering the pattern of grazing by herders and their social relations with farmers. Based on this, Sawin (2013), predicts that an estimated 5 billion people, who constitutes part of the current world population, could be living in water-stressed locations by 2025 . As human population increases coupled with the growth in the population of herd, there is a growing pressure on the fewer available natural resources (Bruesers, Nederlof and van Rheenen. 1998). For Bello (2013), improved conditions of the cattle have often compelled the pastoralist to seek for more pastures beyond their limited range. It is therefore this search for more pastures beyond their limited range that is the heart of the conflict between herdsmen and farmers. Concurring, Homer- Dixon emphasizes the role of resource scarcity and competition as one of the primary causes of the conflict between herdsmen and farmers (Homer-Dixon, 1999). Resources scarcity is essentially a decline in the availability of or access to natural resources induced by climate change.

In summary, scarcity of land, water and foliage which stems from unfavourable weather and climatic condition which reduces the availability of these resources is what usually changes the pattern of grazing by herders and social relations with farmers. As growing pressure on natural resources caused by human population increase, growth in the population of herd (Bruesers, Nederlof and van Rheenen. 1998), due to improved conditions of the cattle often compel the pastoralist to seek for more pastures beyond their limited range (Bello, 2013). The relationship between the pastoralist and farmers becomes competitive over access to and utility of lands and water for cultivation of the part of farmers and herding for the pastoralist (Homer-Dixon, 1999).

\subsection{Proliferation of small arms and light weapons amongst herdsmen}

The proliferation of small arms and light weapon has over the years, indeed, since the return to civil rule been one of the major security challenges confronting the Nigerian society. Readily available and easy to use, small arms and light weapons have been the most important tool of violence in Nigeria, and also in almost every part of the globe. With a huge cache of small arms and light weapons at every nook and cranny of the Nigerian society, the state of being safe or protected against danger or risk has simply collapsed. By implication, internal security management is in a sorry state. Practically speaking, these weapons have taken a heavy toll on human lives, with women and children accounting for nearly 80 percent of the causalities. Basically, the destructive and damaging effects of these weapons have become an issue of serious concern, especially with the emergence of Fulani herdsmen who, though untrained, have been manipulating and employing them to snuff out life of root crop farmers at the least provocation. In other words, hundreds of root crop farmers have been killed or displaced as a result, and their property destroyed. Viewing from a different perspective, Jekada (2005) avers that the proliferation of small arms and light weapons affect the intensity and duration of violence and encourages militancy rather than a peaceful resolution of unsettled differences. Corroborating, Nte (2011) states that the trafficking and wide availability of these weapons fuel political instability and pose a threat, not only to security, but also to sustainable democracy. 


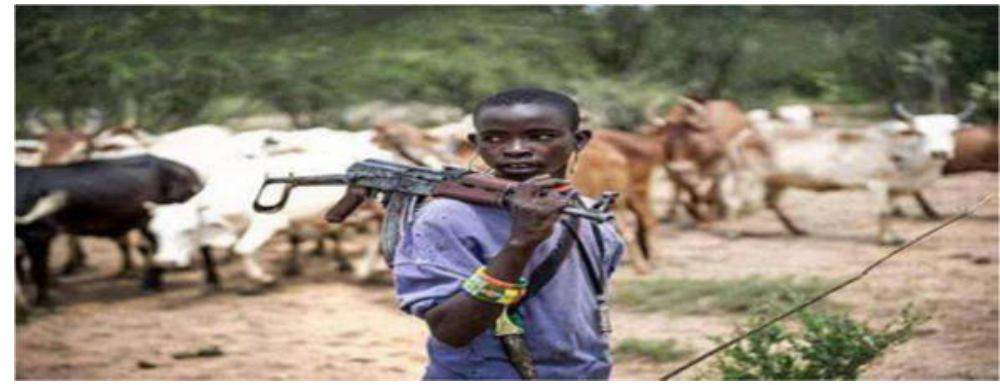

A herdsman with his AK 47 on his shoulders

Small arms, the United Nations General Assembly defines, "as any portable lethal weapon that expels or launches, is designed to expel or launch, or may be readily converted to expel or launch a shot, bullet or projectile by the action of an explosive (Heinrich, 2006). In a similar strand, the United Nations Institute for Disarmament Research highlights small arms to include revolvers and self-loading pistols; rifles and carbines; sub-machine-guns; assault rifles; light machine-gun; heavy machine-guns; hand-held under-barrel and mounted grenade launchers; portable anti-craft guns; portable anti-tank guns; recoilless rifles; portable launchers of antitank missiles and rockets system; portable launchers of anti-aircraft missiles systems; and mortars of calibers less than $100 \mathrm{~mm}$ (United Nations Institute for Disarmament Research (UNIDIR, 2006). On the other hand, light weapons are portable weapons designed for use by several persons serving as a crew: heavy machine guns, automatic cannons, howitzers, mortars of less than $100 \mathrm{~mm}$ caliber, grenade launchers, anti-tank weapons and launchers, recoilless guns, shoulder fired rockets, anti-aircraft weapons and launchers, and air defense weapons (SADC Firearms Protocol, 2003:Article 1.2).

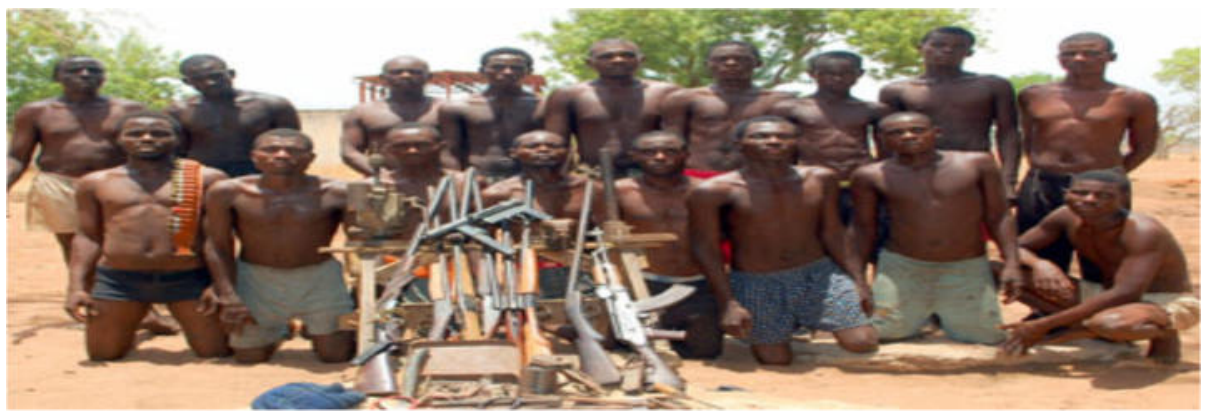

Arrested herdsmen with dangerous weapons

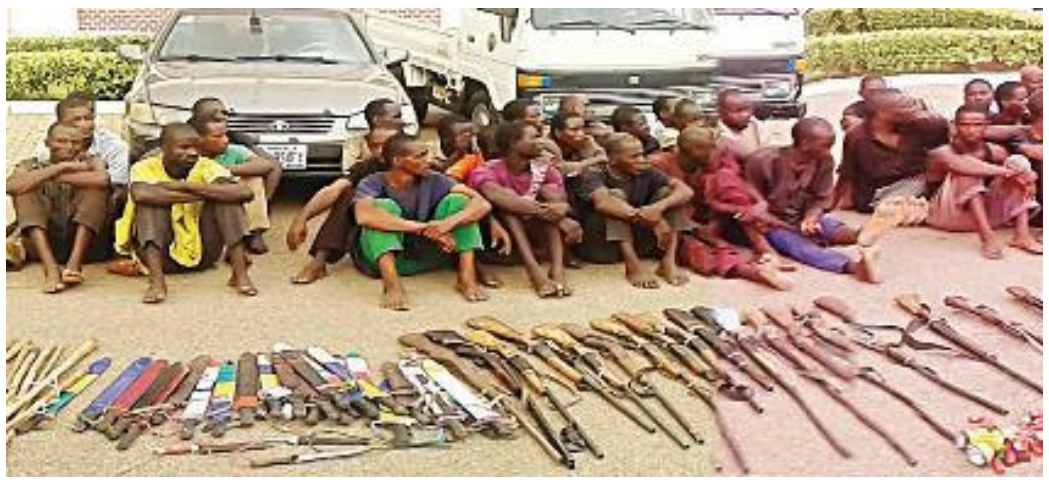

Another badge of Arrested herdsmen with dangerous weapons

The proliferation of small arms and light weapon in the hands of herdsmen in their quest to access pastures for their cattle in the southeast region demonstrates the reality of the climate change and resource control interface. 
The menace posed by Fulani Herdsmen in the different communities they graze their cattle is becoming very upsetting. Clearly, the propensity towards seeking greener pastures for their cattle and in the end destroying undergrowth crops running into hundreds of thousands of naira is more and more constituting major security challenges to their host communities. Shockingly, as many arms and ammunition of various types, size and caliber find their ways into the hands of herdsmen, so is the rise in skirmishes. Consequent upon this, the magnitude of attacks on host communities by Fulani herdsmen has assumed, according to close observers, a sophisticated dimension that more often than not the host communities are overwhelmed by their might. The most pathetic challenge is the gruesome manner in which attacks against farmers are carried out. They slaughter, gorge out their eyes and removed their genitals (Vande-Acka, 2014). In his assessment, Durojaiye (2014) submits there have been escalations of brutal attacks by Fulani herdsmen on natives of the invaded farming communities including women and children in various states across the country. The skirmish over natural resources due to the proliferation of small arms and light weapons is increasingly and dangerously becoming a nightmare. Sequel to this trend, the menace of Fulani herdsmen, in Nigeria, has attracted interest among intellectuals because of their criminal activities in every community they have hobnobbed. Evidently, the incidence of serious cases of disagreements for survival between herdsmen and farmers has led to loss of lives and destruction of properties with the emergence of insecurity due to the continuous desire for vengeance by the parties involved (Pyramid Trust, 2009). One of the most of persistent accusations against Fulani herdsmen in recent times has been that they have been using weapons like Ak-47 assault rifles against sedentary farming communities who have tried to oppose their encroachment into their farmlands. A leading columnist, even blamed top members of the Northern elite as purchasing these weapons for a "Fulani militia" but the truth is much simpler than the conspiracy theories.

Fulani herdsmen are in minority in Nigeria, but when viewed against the policy of government that upholds entry without visas to all Fulani anywhere in the world to migrate to Nigeria, a different picture because of their patronage of small arms and light weapons. Admittedly, the Muslim religious faith allows a man to marry four wives; if the population birth document remains as being projected: one woman, four children; an average Muslim is entitled to sixteen children, while the Christian faith which permits one man to one woman, gets only four children as against sixteen. Consequent upon this wide disparity, and their rising demographics, herdsmen have become so deadly to every segment of the Nigerian society, particularly people of southeast Nigeria whose farmlands have continually been destroyed over time. In the southeast, it is observed, in a rather cynical way, that the level of security is obviously measured almost entirely by the activities of herdsmen. The more violent their invasion of farmlands is, the greater the induced sense of insecurity for root crop farmers. As a result, the level of investments by root crop farmers in their farms is based on understanding the criminal barometer of herdsmen.

What is really surprising in the whole scenario is the sudden transition from sticks carrying herdsmen to control their cattle to the shoulder strapping AK 47 herdsmen who shoot at root crops farmers for protesting against their damaged crops by cattle. Fulani herdsmen killing has become clear and present danger to national security, to peaceful coexistence among the various ethnic groups that cohabit virtually everywhere in the country. It is a fury let loose from the bowel of ancient pastoral

economy and social order. It has become a festering sore on both the physical body and the psyche of the nation. From the use of bows and arrows, daggers and machetes, clubs and other dangerous native weapons, the Fulani herdsmen have migrated to the use of sophisticated AK-47 and other assault rifles. How they came in possession of these modern weapons of destruction, given their cost in the illegal arms market, is also yet a mystery. However, in an attempt to advance reason for the use of weapons like Ak-47 assault rifles against sedentary farming communities, an unidentified herdsman remarks:

Our herd is our life because to every nomad life is worthless without his cattle. What do you expect from us when our source of existence is threatened? The encroachment of grazing fields and routes by farmers is a call to war... wherever we turn we find the land reserved for our cattle to feast, taken over by farmers...it becomes difficult for our herd to move and graze without veering into crop fields...once that happens, the farmers confront us and we have no option but to fight back.

In fighting back to reclaim what was not originally theirs, they often come in surprise attack, finding their victims helpless, unable to defend themselves. They mow down their victims and butcher them showing the 
grotesque cruelty involved in such dastardly attacks. Physical attacks are often accompanied by arson, again, showing the base satanic level to which they have sunk in order to prove their uncommon cruelty and hatred for their victims. But why their victims always remain defenseless is also a mystery in itself (Ekemenah, 2017). Countering the assertions of the unidentified herdsman on why they fight back, a root crop farmer says:

In the past, the migration used to be more in the middle of the dry season and after harvest but nowadays it is throughout the year. Worst of all during planting season, they (Fulani herdsmen) walk on seeds planted, and in most cases a lot of the seeds fail to germinate. This has caused huge loss to us. The damage is usually the cause of our conflicts with the Fulani herdsmen. It is a yearly battle between us.

Agreed, the struggle for diminishing resources as a result of climate variability has increased significantly, and thus provoking clashes between herdsmen and root crop farmers. The dwindling availability of water and pasture to herdsmen, whose very existence depend on these have resulted to hundreds of deaths. Since these root crop farmers produce more than 70 percent of Nigeria's food, leaving this critical lifeblood of the country's economic and cultural life at the mercy of herders and their cattle is not an option, but this key economic sector is under siege. Whatever direction the pendulum between herdsmen and root crop farmers swings, it is obvious that climate change is a major contributor to this clash. Accepted, since the Fulani herdsmen are completely dependent on resources of the natural environment for the survival of their cattle, they go all out to get these resources at whatever cost. This is subscribed to by Barnett (2008) who argues that "there are different levels of vulnerability to climate change. Those impacted most are likely to be those who depend on natural resources and ecosystem services for their livelihoods.

Though, it has argued that herdsmen and farmers conflicts in southeast tend to signal an ulterior jihadist agenda. The attacks are sometimes shrouded in mystery and diabolism. A situation where a multitude of community men are held helplessly captive and slaughtered without any resistance or gun shots depicts elements of clairvoyance. This is because "most of the persons that were slain by their assailants during the crisis at Ayilamo were captured with little or no resistance... to prove this there were no bullet wounds on some of the bodies that were recovered" (Vande-Acka, 2014). Based on this, there is a perception of state impunity for the herders, given the evident lack of resolve to rein them in. Noble Laureate, Wole Soyinka, has said the government's response smacks of abject appeasement and encouragement of violence on innocents. Nigeria needs an urgent response before the current crisis festers like the Boko Haram malaise.

Be it as it may, this insensitivity and nonchalant attitude of government, particularly her silence has constituted serious threats to the means of survival and livelihoods of both the farmers and herdsmen and what both groups are tenaciously protecting. Unfortunately, the unwholesome activities of herdsmen which, have been impacting negatively on the various segments of society; creating the psychological basis for uncertainty are further compounded by the intense use of presidential authority to cover up and dismiss these detestable killings of farmers and wanton destruction of their farm crops running into billions of naira in the entire zone as being the handiwork of foreigners, while doing nothing to halt the incessant atrocities against farmers without any meaningful statement from the government of the day this time past. Thus, it is assumed that the silence in a way concurs with the widely held assertion that the government has overtly taken a position.

From the foregoing, it is evident that climate change has constituted a great threat by putting great pressures on the dry land and thus provoking conflicts between herdsmen and root crop farmers. The struggle for diminishing resources as a result of climate variability has increased significantly. In other words, the dwindling availability of water and pasture to herdsmen, whose very existence depend on these have led to the struggle for control over who owns the land. Whatever direction the pendulum swings, climate change is a major contributor to resource conflict in Nigeria's southeast.

However, while the resource conflicts between herdsmen and farmers have continued unabated over the years, there is a new twist to the whole scenario. The new narrative seems to fuel apprehensions of an ulterior jihadist agenda. This has a significant security dimension that can easily be exploited because government insensitivity and nonchalant attitude, particularly her silence has constituted serious threats to the means of survival and livelihoods of farmers in the southeast of Nigeria. Furthermore, amongst the people of southeast Nigeria, government silence in a way agrees with the widely held assertion that the government is behind the herdsmen to 
continue to ensure that their cattle are provided for at the expense of the root and tuber farmers who obviously have none of their own in government. Whether erroneous or not, the unwholesome activities of herdsmen have been impacting negatively on the various segments in the southeast, and creating the psychological basis for uncertainty which is further compounded by the intense use of presidential authority. This power seems to cover up and dismiss the detestable killings of farmers and wanton destruction of their farm crops running into billions of naira in the south east geo-political zone as being the handiwork of foreigners from Libya, while doing nothing to halt the incessant atrocities against farmers therein. Given the evident lack of resolve by government to rein in the herders, there is a perception of them enjoying state power. Noble Laureate, Wole Soyinka, in one of discussions, argues that the government's response smacks of abject appeasement and encouragement of violence on innocents. In other words, Nigeria needs an urgent response before the current crisis festers like the Boko Haram malaise.

\section{Discussions of findings}

This section deals with the analysis of research questions formulated and the presentation of the findings of the study. Data collected from in-depth interviews (IDI) and focus group discussion (FGD) adopted for the analysis. As earlier noted, the major objective of this research work is to examine the threats of climate change, herdsmen migration and the proliferation of arms: issues, challenges and the way forward in southeast Nigeria. In-depth interviews and Focus group discussions were conducted to gather data on the threats of climate change, migration of herdsmen and proliferation of arms amongst herdsmen in the southeast Nigeria.

\section{Research Question1: How does the impact of climate change affects herdsmen migration?}

From the In-depth interview (IDI), and Focus group discussions, discussants and interviewees unanimously agreed climate change has the potentials of triggering severe disruptions with disastrous consequences for the people. The herder-farmer crisis demonstrates the reality of the climate change and resource control interface, and its embedded security challenges. The scarcity of water and shrinking of grazing fields in the desert north appear to be pushing herders southwards to the grasslands of the savannas and forests. Sequel to this, discussants contended that the persistent droughts and desertification in the northern part of Nigeria has forced herdsmen to migrate southeast in search of green pastures for their cattle; this has been a significant factor in many environmental conflicts leading to violence in which lives and properties running into millions of naira have been lost; a consequence of climate change. Essentially, climate change is a great facilitator of resource conflicts; this potential is to a reasonable extent determined by migration and other variables like attitude of the immigrants on the one hand and perception, reception, response and cordial relationship with host communities on the other hand. With the effect of climate change not lessening, the skirmish over natural resources, namely water and grazing fields, could become direr as the impact of climate change takes hold. When the host communities attempt to request the exit of herdsmen as a result of the dwindling natural resources, refusal to grant access to herdsmen through their farm lands because of the fear of destroying their crops by their cattle, the Fulani herdsmen become aggressive and attack the host community sometimes with the assistance of hired mercenaries. Fulani herdsmen normally attack their target communities at the time they are most susceptible such as mid-night or when they are in their churches, incessantly killing people with sophisticated weapons, looting properties and burning houses (Durojaiye, 2014).

From the foregoing, discussants and key informants are convinced that struggle for diminishing land resources in the guinea savannah and rainforest belt of Nigeria is increasing due to uncertainties and climatic variability that already had terrible telling effects on farmers (including herdsmen) of the Sahel and upper Sudan zones. From all available primary data, the desperation to find feeds for their cattle have led to the wanton destruction of root crops of farmers. Basically, Crop farmers produce more than $80 \%$ of Nigeria's food. Leaving this critical lifeblood of the country's economic and cultural life at the mercy of herders and their cattle is not an option. Farmers, the majority of whom are women, constitute the bedrock of the country's informal economy.

Basically, since the assumption of President Muhammadu Buhari as president of Nigeria, scholars, particularly non-northern scholars have averred that Muhammadu Buhari (a Fulani), is pursuing the Islamization of Nigeria going by the long silence of government on the unwholesome activities of Fulani herdsmen. They cited the case of the recent massacre of 77 persons in Benue state, which he never commented on, but rather chose to embark on electioneering campaigns. By his actions, Nigeria has become more polarized, very fragile and delicate 
union of culturally diverse ethnic groups today than ever before along ethno-religious lines. In reaction, the State Governor, Samuel Ortom remarked: I am a member of the APC but I cannot keep quiet when my people are being annihilated, I will not accept that because I cannot be governor over dead people. I'm not a dead man either. According to him:

The responsibility of enforcing the law is that of the Federal Government. That is why I have joined the voices calling for the restructuring of the country. Because we cannot have an IGP who is the mouthpiece of Miyetti Allah and we cannot have a minister who should be protecting the territorial integrity of this country coming out to say it is foreigners that are responsible for the killings. "We cannot have a security architecture that is not ready to protect lives and property. That allows herdsmen carry guns and displaying it openly.

Not satisfied yet in his outburst, the governor thundered that:

Today herdsmen have also taken over kidnapping in the country from North to South because they have guns and are being protected by the IGP and when you talk they start calling you names. I must send a message that Samuel Ortom is not a drowning man.

Based on the stated burning issue, Governor, Samuel Ortom deflected to the Peoples Democratic Party from the All Progressive Congress (APC) where he got re-elected for a second term. DDD According to Abati(2016), there has been so much emotionalism developing around the subject of the recent clashes between nomadic pastoralists and farmers, and the seeming emergence of the former as the new Boko Haram, forbidding not Western education this time, but the right of other Nigerians to live in peace and dignity, and to have control over their own geographical territory. From Benue, to the Plateau, Nasarawa, to the South West, the Delta, and the Eastern parts of the country, there have been very disturbing reports of nomadic pastoralists killing at will, raping women, and sacking communities, and escaping with their impunity, unchecked, as the security agencies either look the other way or prove incapable of enforcing the law. The outrage South of the Sahel, according to Abati (2016), is understandable. It is argued, rightly or wrongly, that the herdsmen has been overtaken by a certain sense of unbridled arrogance arising from that notorious na-my-brother-dey-power mentality and the assumption that "the Fulani cattle" must drink water, by all means, from the Atlantic Ocean. The herdsmen indisputably represent a significant component of the Nigerian economy. They constitute the major breeders of cattle, the main source of meat, the most available and cheap source of animal proteins consumed by Nigerians. The Fulani own over $90 \%$ of the nation's livestock population which accounts for one-third of agricultural GDP and 3.2\% of the nation's GDP (Eniola, 2010). Furthermore, the contribution of the Fulani to the local food chain and national food security cannot be overstressed. Therefore, government cannot continue to allow these conflicts to continue.

\section{Research Question 2: What is the security implication of climate change on the proliferation of small arms and light weapons in the hands of herdsmen?}

The proliferation of small arms and light weapons amongst herdsmen in the country has been very disturbing. For example, the conflicts orchestrated by herdsmen in Benue State had claimed the lives of more than 5000 victims in the first half in the year 2014. With the massacre of farmers in Benue State by herdsmen, the erstwhile Senate President, David Mark, described the senseless attacks as "genocide against his people". Corroborating the assertion of David Mark, Vande-Acka(2014) avers that the herdsmen's attacks are sometimes shrouded in mystery and diabolism. This, he argues, is because "most of the persons that were slain by their assailants during the crisis at Ayilamo were captured with little or no resistance... to prove this there were no bullet wounds on some of the bodies that were recovered". At this juncture, a school of thought opines that a situation where a multitude of community men are held helplessly captive and slaughtered without any resistance or gun shots depicts elements of clairvoyance.

Aside this element of clairvoyance, researchers are very justified to be anxious about herdsmen who carry AK47 guns while rearing their cattle. Studies have showed that they are ever ready and given their sophistication to attack host communities, and most times said to be heavily protected with state of the art military convoys. Thus, the persistent attack by the herdsmen has shown that recent operational strategy and tactics of herdsmen suggest infiltration of the rank and file of communities in the southeast. What this really portend is dangerous as 
it reveals to a great extent the insecurity of Igbo communities. By implication, the issue concerning the whole episode is lack of respect for the laws, and the impunity and callousness the herdsmen display in grazing their cattle on other people farms and attacking the same people when they protest. On the whole, discussants unanimously agree that the challenge is lack of consideration for others. They described the arrogant submission of the Miyetti Allah Cattle Breeders Association that Fulani herdsmen have the right to graze their cattle on any ground, irrespective of the owners' protests or what is planted on the land and, that the people of the southeast owe Fulani herdsmen grass for their cattle as provoking and upsetting. To the discussants: It is the height of insensitivity and abuse of power, to pay no attention to the damage their cattle do to the investment of farmers and the rights of the victims of their terror. Despite this, discussants clearly agree that:

there is a relationship between climate change and herdsmen migration, but this relationship should not turn herdsmen into murderous psychopaths, who go on killing and burning spree, dismembering the bodies of their victims and reaping out their hearts after subjecting them to the worst barbaric inhumanity the mind of men can conjure.

With all these incidences, a consensus of opinions hold that since the assumption of the president, Muhammadu Buhari, a Fulani, he has not been proactive in curtailing the menace of herdsmen, but rather the government inability to make any arrest seem to suggest covertly that the herdsmen are being protected by government. This assertion is buttressed by the unwholesome activities of herdsmen which have over time impacted negatively on the various segments of society. Furthermore, the dismissal of the detestable killings of farmers by herdsmen as being the handiwork of foreigners, while doing nothing to halt the incessant atrocities against the root and tuber farmers in the south remains worrisome for a government that claims to respect human lives. Extending this line of argument, discussants contended that some traditional and farming communities in the southeast have been overrun by herdsmen who graze their cattle on crop fields destroying the livelihoods without any meaningful statement from the government this time past. Thus, it is assumed that the silence in a way corroborates with the widely held view the government is behind the herdsmen. Be it as it may, this nonchalant attitude of government, particularly her silence has constituted serious threats to the means of survival and livelihoods of the farmers.

This assumption of non-northern scholars seems to corroborate with what Professor Wole Soyinka's assertion that the conflicts (though provocative) over access rights to farmland have become ubiquitous and seem to have tilted, particularly under President Muhammadu Buhari to favour herdsmen. Unfortunately, BB the unwholesome activities of herdsmen have been impacting negatively on the various segments in the southeast, and creating the psychological basis for uncertainty which is further compounded by the intense use of presidential authority. This power seems to cover up and dismiss the detestable killings of farmers and wanton destruction of their farm crops running into billions of naira in the south east geo-political zone as being the handiwork of foreigners from Libya, while doing nothing to halt the incessant atrocities against farmers therein. From this viewpoint, the discussants wholeheartedly submit that the menace posed by Fulani Herdsmen in the different communities in the southeast they have been to for purposes of grazing their cattle is becoming very alarming as their activities are more and more constituting major security challenges to their host communities. The propensity towards engaging the land and farm owners of the sites they graze their cattle is increasing by the day as they update their arsenal with highly sophisticated weapons. Therefore, given the evident lack of resolve by government to rein in the herders, there is a perception of them enjoying state power.

As it were, the Institute of Economics and Peace (2015) has rated the Fulani herdsmen as the fourth most deadly terrorist group in the world as at 2014. Global Terrorism Index report records the dramatic increase in the attacks by herdsmen from 2010 to 2013 with 80 deaths recorded to a skyrocketing increase in the death toll to 1,229 in 2014 alone. Unlike deaths from Boko Haram which are mainly in the North, the southeast has not been left out in the mayhem. For example, on the 25th of April, 2016, seven villages in Ukpabi-Nimbo town a border town in Uzo Uwani in Enugu State was attacked by heavily armed herdsmen who killed and left many injured (Ikenwa and Adeyemi, 2016). In the absence of state protection, the clashes between herdsmen and farmers strike at the core of Nigeria's vulnerable ethno-political fault lines. According to scholars, particularly, the Noble Laureate, Wole Soyinka: 


\begin{abstract}
....the government's response smacks of abject appeasement and encouragement of violence on innocents' crop farmers, the majority of whom are women, produce more than 80 percent of Nigeria's food and thereby constituting the bedrock of the country's informal economy. Leaving this critical lifeblood of the country's economic and cultural life at the mercy of herders and their cattle is obviously not an option.
\end{abstract}

Obviously, with these killings here and there, Nigeria has become more polarized, very fragile and delicate union of culturally diverse ethnic groups today than ever before along ethno-religious lines. With this bad blood already in the air, there is the need to quickly address the forces that spreads division while at the same time promoting the forces of unity. In line with this conception, the former speaker of the House of Representatives, Yakubu Dogara on the 26th of April, 2016 calls for "deliberate and proactive actions to end the incessant farmers and herdsmen clashes spreading across the country, noting that if not properly checked could divide Nigeria"'(Ovuakporie and Agbakwuru, 2016).

\title{
6. Conclusion and Recommendations
}

This study has demonstrated that the main reason for the conflict is not just about climate change, but the total disregard and contempt with which herdsmen show in grazing their cattle on sedentary farmers' crops thereby destroying their livelihood, while securing the well being of their own. While this is not acceptable to the root and tuber farmers due to the attendant consequences, the proliferation of small arms and light weapons by herdsmen in their quest to access another farmland with impunity has become frightening and leading to the deaths of several hundred Nigerians.

Admittedly, the migration of herdsmen down to southeast of the country is principally due to the fact that desertification and other environmental challenges have left their immediate environment bereft of pastures thereby compelling their migration in search of pasture and water, but the way and manner this search for greener pastures is being sought leaves much to be desired.

Based on the conclusion, the following recommendations are made to ensure that the resultant effects of climate change and herdsmen migration are addressed.

1. Nigeria's cattle are an essential part of securing Nigeria's food security. The 19th century farming practices that the herdsmen rely on can no longer be sustained. In this vein, government should address the dictates of the Kyoto Protocol with respect to reducing the emission greenhouse gas and other harmful emissions in order to save our environment and contain radical climate change.

2. Nigeria is a complex country and therefore government should not support herdsmen who are predominantly Fulani because President Mohammad Buhari is Fulani. Rather government should be concerned about the unwholesome activities of herdsmen, particularly the wanton destruction of farm crops by herdsmen and summon the courage to condemn the invasion of farmlands by herdsmen and put a halt to the menace.

3. There should be legislation to remedy the effect of desertification in the Sahel region and other Fulani communities. Government should come up with policies to create grazing reserves and dams for pasture and water in states that are predominantly Fulani so that they do not stray long distances in search of pastures. In other words, this will encourage the herders to accept the sedentary life. Furthermore, it is certain that since climate change has come to stay, it is important for government to put more machinery on ground particularly in the north because over 70 percent of the nation's food crop comes from the region by encouraging climate change mitigation and adaptation. Further, climatologic research should be enhanced to combat desert encroachment, and in the long run reduce inherent conflicts in issues of climate change

4. Furthermore, there should be a deliberate design to enlighten and mobilize both the herdsmen and farmers on the need to understand the ecology and the resources available in the locality. When this is done, it will open a window for interdependence between the herdsmen and the farmers in the optimal 
use of the resources for collective benefit and equitable access. Thus, the place and space must be exploited for common interest with effective regulation of activities, behaviour and conduct for sustainable peace to reign.

5. Land cover changes are an important index of climate change. In the Nigerian environment just like in any other parts of the tropical world, land cover changes result mostly from combination of natural and anthropogenic influences. The main natural force is rainfall changes induced by climatic variability. This reduces the natural regeneration rate of land resources. This also presents a chain of causal reaction that makes people exploit more previously undisturbed lands. In Nigeria, the rate of human regeneration of natural resources through re-afforestation is very low. Hence, there is the tendency to abandon a piece of land once it is no longer productive or cannot produce enough to support grazing animals.

6. Since herdsmen are completely dependent on pastures, government should develop a sustainable strategy for providing water and plant-based food requirements to support current and future populations of cattle. In this vein, government should be concerned about the unwholesome activities of herdsmen, particularly when it involves the wanton destruction of farm crops by herdsmen. Government should ensure that the escalation of conflicts between herdsmen and farmers is halted in order to create a harmonious coexistence and security. This will, among other things, enhance the security of the cattle, to access grazing space or resources without pouncing on farmers' crops.

\section{REFERENCES}

\section{Personal Communication (PC; Oral Interviews)}

Interview conducted with local chiefs in Ezeukwu, Bende LGA, Abia State December 14, 2019

Interview with residents of Ahaba Imenyi village, Isuikwuato on 6 January, 2019

Interview with two residents of Ivo LGA, Ebonyi State on 8 October,, 2019

Interview with some residents of Uzo Uwani on 12 October, 2019

Interview with some Catholic priests of Enugu Catholic Diocese, Uzo Uwani LGA, 15 October, 2019

Unpublished Document of Internally Displaced Persons in Uzo Uwani, Enugu State

\section{Published Materials}

Abbas, I. M.. No Retreat No Surrender Conflict for Survival between Fulani Cattle Herders and Farmers in Northern Nigeria, in European Scientific Journal, 8(1), 331-349, 2009

Abubakar, M. B. Sociological Assessment of Nomadic Pastoralist and Sedentary Farmers Conflicts in Katsina State; An unpublished M.Sc. Thesis submitted to Sociology Department, Ahmadu Bello University, Zaria, 2012

Adebayo, O. and Olaniyi, A. Factors Associated with Pastoral and Crop Farmers Conflict in Derived Savannah Zone of Oyo State Nigeria, in Journal of Human Ecology, 23(1), 71-74,2008

Anderegg, L.D., W.R. Anderegg, and J.A. Berry. Not all droughts are created equal: Translating meteorological drought into woody plant mortality. Tree Physiology 33 (7), 2013 https://doi.org/10.1093/treephys/tpt044.

Aaron S. Climate Change Adaptation and Conflict in Nigeria: Special Report Washington, DC: United States Institute of Peace, 2011

Ahima Caleb S. Fulani Herdsmen Attack Wukari, Taraba State, April, 2014

Ajala, M. Socio-economic Factors influencing Dairying among the Agro Cattle Herders in the Nigerian Guinea Savanna of Nigeria" An unpublished Ph.D Thesis submitted to the Department of Agricultural Economics and Rural Sociology, Faculty of Agriculture, Ahmadu Bello University, Zaria, 2000

Akevi John . Addressing the scourge of Fulani Herdsmen in Benue State, Eagle Reporters Journal, Apr 18, 2014

Azeez O, Michael F, and Ufo O.U. The Cattle are "Ghanaians" but the Herders are Strangers: Farmer-Herder Conflicts, Expulsion Policy, and Pastoralist Question in Agogo, Ghana. African quarterly 15 (2): pp 5467,2015

Babajide Johnson .Benue residents raise the alarm over influx of Fulani herdsmen, Nigerian Tribune Newspaper, July 8, 2014

Barnett, J. Climate change, human security and violent conflict. Tyndall Centre for Climate Change Research and CSERGE, School of Environmental Sciences, University of East Anglia, Norwich NR4 7TJ, UK, 2008 
Bassett, T.J. Fulani Herd Movements. Geographical Review, 26(3): 234- 248, 1986.

Bello, A.S. Herdsmen and Farmers Conflicts in North-Eastern Nigeria: Causes, Repercussions and Resolutions. Academic Journal of Interdisciplinary Studies.2 (5):29-39, 2013

Benjamin T. Gudaku 'Environmental Refugees, Migration and Fulani Attacks on Autochthonous Christian Tribes of Nigeria's Middle Belt: Signal of Boko Haram and Al-Qaeda Inspired Jihad', unpublished article, p.2May 2014

Biermann, F., \& Klaus, D. Global Environmental Change and the Nation State. Global Environmental Politics 4(1):1-22, 2004

Blench, R.M. Conflict between pastoralists and cultivators in Nigeria, Kay Williamson Educational Foundation Cambridge, 2010; Retrieved on Oct 2, 2016 from www.rogerbtench.infor/RBOP.htmiew

Breusers, M. Nederlof, S. and van Rheenen,. T. Conflict or Symbiosis? Disentangling Farmer-Herdsman Relations: The Mossi and the Fulbe of the Central Plateau, Burkina Faso. Journal of Modern African Studies 36(3):357-380, 1998

Ezeomah, C. Land tenure constraints associated with some recent experiments to bring formal education to nomadic Fulani in Nigeria. Overseas Development Institute Agricultural Administration Unit Paper 20D, London, 1985

Ezirim, G.E. and Onuoha, F.C. "Climate Change and National Security: Exploring the Theoretical and Empirical Connections in Nigeria”, Journal of International Politics \& Development, Vol.4; Nos. 1\& 2, 2008

Fasona, M; Fabusoro, E; Sodiya, C; Adedayo, V; Olorunfemi, F; Elias, P. O; Oyedepo, J; \& Oloukoi, G. Some Dimensions of Farmers'-Pastoralists' Conflicts in the Nigerian Savanna, Journal of Global Initiatives: Policy, Pedagogy, Perspective, 10 (2): 87- 108, 2016

Flavel, A. Migration. In V. Ndaruzaniye, L. Lipper, D. Fiot, A. Flavell \& J. Clover Eds.), Climate Change \& Security in Africa: Vulnerability Discussion Paper of Climate Change, Environment and Security (ACCES) Conference, 2010

Homer-Dixon, T. Environment, Scarcity and Violence. New Jersey: Princeton University Press, 1999

Homer-Dixon, T “Terror in the Weather Forecast,” New York Times, April 24, 2007.

Houdret, A., Kramer, A. \& Carius. The Water Security Nexus: Challenges \&Opportunities for Development Cooperation Deutsche Gesellschaft für Technische Zusammenarbeit, 2010

IPCC (Intergovernmental Panel on Climate Change). Climate Change 2007 Synthesis Report: Contribution of Working Groups I, II, and III to the Fourth Assessment Report of the Intergovernmental Panel on Climate Change. Cambridge: Cambridge University Press, 2007

IEP. Global Terrorism Index. Measuring and Understanding the Impact of Terrorism. Institute of Economics \&Peace .USA, 2015

Ikenwa, C. And Adeyemi, E. Enugu massacre planned in kogi suspect confesses.Sunnewsonline.com/enugumassacre-planned-in-kogi-suspect-confesses/ 2016

Ikumola, D.A.(2010) The Socio-Economic Implication of Climatic Change, Desert Encroachment and Communal Conflicts in Northern Nigeria". Being a Research Paper Presented at the 250th Anniversary Conference of the Royal Norwegian Society of Sciences and Letters (Det)2010

Ingawa, S. A; Ega, L. A and Erhabor, P.O . Farmers - Pastoralist conflict in Core- States of the National Fadama Project, FACU, Abuja PP.11-27, 1999.

Karmaoui, Ahmed (2019) Drought and desertification in Moroccan Pre-Sahara, Draa valleys: exploring from the perspective of young people. Karmaoui Geoenvironmental Disasters, 6:2, 2019 https://doi.org//doi.org/10. 1186/s40677-019-0118-8

Ludovica Iaccino. Nigeria Fulani militants: Herdsmen accused of killing 1,200 people in 2014, International Business Times, United Kingdom, 2015

Mugenda, O. M. \& Mugenda, A. G. Research Methods: Quantitative \& Qualitative Approaches, 1999

Ofuoku, A. U. and Isife, B. I. Causes, Effects and Resolution of Farmers-Nomadic Cattle Herders Conflicts in Delta State, Nigeria. In International Journal of Sociology and Anthropology, 1(2):49, 2009

Okeke, O.E. Conflicts between Fulani Herders and Farmers in Central and Southern Nigeria: Discourse on Proposed Establishment of Grazing Routes and Reserves. AFRREV IJAH International Journal of Arts \& Humanities 3(1), pp 66-84, 2014

Olayoku, P.A. Trends and patterns of cattle grazing in Nigeria. IFRA-Nigeria working papers series,2014

Orodho, J. (2009) Elements of Education and Social Science Research Methods. Kenezja Publisher, Maseno, Kenya

Osadebe, C.C, and Akpokodje, E.G Statistical analysis of variability in properties of soils in gully erosion sites of Agulu-Nanka-Oko area, southeastern Nigeria. Journal of Mining Geology 43 (2): 197-202, 2007

Ovuakporie, E and Agbakwuru, J Herdsmen, farmers' clashes threat to Nigeria'sexistenceReps.www.vanguardngr.com/2016/04/clashes-farmer Threat-Nigeria's existence-reps/2016 
Ozobu Justice E. .Fulani Herdsmen invade Enugu Communities, 2 Killed, 3 Women Raped, 2014

Purvis, N., \& Busby, J. The Security Implications of Climate Change for the UN System. In Policy Brief for the United Nations and Environmental Security, 2008

Pyramid Trust. "Jigawa Cattle Rearers, Farmers in Bloody Battle” Sunday, 19 July, 2009

Sawin, J. Climate Change Poses Greater Security Threat than Terrorism. In World Watch Institute Journal, 2013.Available at:http://www.worldwatch.org/node/77

United Nations. United Nations Millennium Declaration, 5/2.2000. Online.(http://www.un.org/millennium/declaration/ares552e.pdf)

United Nations. The Addis Ababa Action Agenda of the Third International Conference on Financing for Development. 2015. Online. (http://www.un.org/ga/search/view_doc.asp?symbol=A/CONF.227/L.1)

United Nations. Transforming our world: the 2030 Agenda for Sustainable Development. Sustainable $\begin{array}{llll}\text { Development } \quad \text { Knowledge } & \text { Platform, }\end{array}$ sustainabledevelopment.un.org/post2015/transformingourworld)

Valerie, N. Water Security. In Ndaruzaniye, V, Lipper, L. Fiot, D., Flavell A, \& J.Clover (Eds.), Climate Change and Security in Africa: Vulnerability Discussion Paper of Climate Change, Environment and Security (ACCES) Conference, 2010

Vande-Acka Tor. Tiv/Fulani crisis: Precision of attacking herdsmen shocks Benue farmers, Daily Independence Newspaper, July 08, 2014 